\title{
Synthesis of Anti-biofoulant Green Nanoparticles Embedded Cellulose Acetate Membranes ${ }^{\dagger}$
}

\author{
Yusuf Wibisono 1,2,*, Shari Amalia Rachmawati 1, Vera Septyaningrum Mylani 1, Nimatul Izza 1, \\ Angky Wahyu Putranto ${ }^{1}$ and Shinta Rosalia Dewi ${ }^{1}$
}

Citation: Wibisono, Y.; Rachmawati, S.A.; Mylani, V.S.; Izza, N.; Putranto, A.W.; Dewi, S.R. Synthesis of Anti-Biofoulant Green Nanoparticles Embedded Cellulose Acetate Membranes. Proceedings 2021, 69, 41. https://doi.org/10.3390/ CGPM2020-07199

Published: 4 November 2020

Publisher's Note: MDPI stays neutral with regard to jurisdictional claims in published maps and institutional affiliations.

Copyright: $\left(C^{2} 2020\right.$ by the authors. Licensee MDPI, Basel, Switzerland. This article is an open access article distributed under the terms and conditions of the Creative Commons Attribution (CC BY) license (http://creativecommons.org/licenses/by/4.0/).
1 Bioprocess Engineering, Brawijaya University, Malang 65141, Indonesia; amaliashari4@gmail.com (S.A.R.); septyaningrumvera@gmail.com (V.S.M.); izza_nimatul@ub.ac.id (N.I.); angkywahyu@ub.ac.id (A.W.P.); Shinta.Dewi@nottingham.ac.uk (S.R.D.)

2 MILI Institute for Water Research, Kawasan Industri Jababeka, Bekasi 17530, Indonesia

* Correspondence: Y_Wibisono@ub.ac.id; Tel.: +62-341-571-708

+ Presented at the First International Conference on "Green" Polymer Materials 2020, 5-25 November 2020; Available online: https://sciforum.net/conference/CGPM2020.

\begin{abstract}
Membranes were used in many aqueous applications, including in food processing, e.g., clarification of fruit juices. Typical drawbacks of membrane processes are membrane fouling, which promotes deterioration of processed products. During application of membranes for fruit juice clarification, biofouling occurred as the process deals with food substances. Biofouling is commonly dominated by bacterial attachment and growth on membrane surface, following the deposition of organic molecules from food substances. Natural antibiotics such as Olea europaea leaves extract might be used to improve the antibiofouling properties of membranes due to its phenolic contents. In this work, Olea europaea substances were obtained by extraction to get the green active solid nanoparticles. Phenolic green nanoparticles then filled into cellulose acetate as membrane matrix. The mixed matrix membrane, therefore, has a safe antibiofouling properties and is suitable for food application. The anti-biofoulant effect has been proven by decreasing bacterial attachment down to $23 \%$ from initial condition, especially for Gram-negative bacteria such as Eschericia coli.
\end{abstract}

Keywords: mixed matrix membranes; cellulose acetate; green nanoparticle; biofouling; bacterial adhesion

\section{Introduction}

Membrane is an up-and-coming technology for liquid-solid separation, including in food substances. Food substances could be separated by using microfiltration and ultrafiltration membranes, depending on their molecular size [1]. Fruit juice clarification is an example of the application of microfiltration membrane for food processing to reduce dissolved solids in juice fluids or to produce clearer liquid. Previous reports on the application of membrane for juice clarification can be found elsewhere in the literature; for instance, for pineapple [2] and kiwi juices [3].

The major drawback of membrane application for food processing is biofouling, as the membrane deals with food substances. Biofouling is biological materials that adhered on the membrane surface and hindered the membrane processes [4]. Bacterial attachment is the most common phenomena on the membrane application of food processes.

Several attempts have been made to minimize the negative effect of fouling, from physical cleaning [5] to membrane surface engineering [6]. This work is focusing on the use of antifoulant agents that inhibit biofouling attached and developed on the membrane surface. Instead of using chemical agents [7] or toxic compounds [8], the use of natural and green antibiotics such as Olea europaea leaves extract nanopowders impregnated into cellulose acetate matrix, is evaluated against biofouling. 


\section{Experiments}

The phenolic solid nanoparticles were extracted from Olea europaea leaves by microwave assisted extraction (MAE) and followed by maceration. During the extraction, some parameters such as solid to solvent ratio and extraction time have been evaluated. Variations of solid to feed ratio of 1:4, 1:6, 1:8 w/v and microwave heating time of 2, 3, 4 min, have been investigated. The phenolic green extracts were quantified by using UV/Vis Spectrophotometer and the data were then analyzed using ANOVA and a Least Significant Difference test. In addition, the powder extract was also characterized by using FTIR and particle size analyzer to determine the functional groups that exist in extracts qualitatively and to measure the size of phenol extracts, respectively.

The particles were then impregnated into cellulose acetate solution to form mixed matrix membrane via phase inversion method. The concentration of nanoparticles were $0.5,0.75$ and $1 \%$, respectively. The membrane was produced then evaluated in term of mechanical strength, mass transfer properties and anti-biofouling properties. Membrane coupons were immersed in E-coli solution for 4,8 and $24 \mathrm{~h}$ to determine the effect of natural anti-biofoulant concentration.

\section{Results and Discussion}

\subsection{Extraction of Green Nanoparticles}

The results of the FTIR test on olive leaf extract shows absorption at waves 3401.03 $\mathrm{cm}^{-1}$, which indicates the phenol compounds present. The phenol compound is observed at a wave frequency between $3590-3650 \mathrm{~cm}^{-1}$ and $3200-3600 \mathrm{~cm}^{-1}$. The phenolic extracts were dried by using a rotary vacuum evaporator to obtain solid particles, and grinded to get into smaller nanoparticles used as filler in cellulose acetate matrix during membrane synthesis.

The phenolic compound acts as green nanoparticles to inhibit bacterial adhesion onto membrane surface when impregnated in cellulose acetate matrix. The presence of small amounts of phenolic substances are still tolerable for membrane application for juice clarification, compared with another toxic substances such as silver nanoparticles. The phenolic green nanoparticles are expected to contact with bacterial cells when attached to membrane surface and disrupt the microbial cells, and furthermore prevent the continued growth of biofouling on the membrane surface. Although the effect might be effective in the first stage of biofouling formation, is still crucial to delay further growth of biofouling.

\subsection{Mixed Matrix Membrane}

The membrane was prepared by phase inversion method, and the mixed matrix membrane formed in fingerlike macropores with the pore size is in microfiltration membranes range.

As shown in Figure 1, the macropore diameter is approximately $20-40 \mu \mathrm{m}$ and acts as supporting layer for thin filtration layer on top of the mixed matrix membrane. The top layer of this asymmetric membrane is approximately $3-5 \mu \mathrm{m}$. As shown in the inset figure, Olea europaea phenolic green nanoparticles clearly found in the surface of membrane pores, and filled in cellulose acetate matrices. These green particles embedded in the polymer matrix, and were expected to become anti-biofouling agents against bacterial adhesion on the membrane surface. 


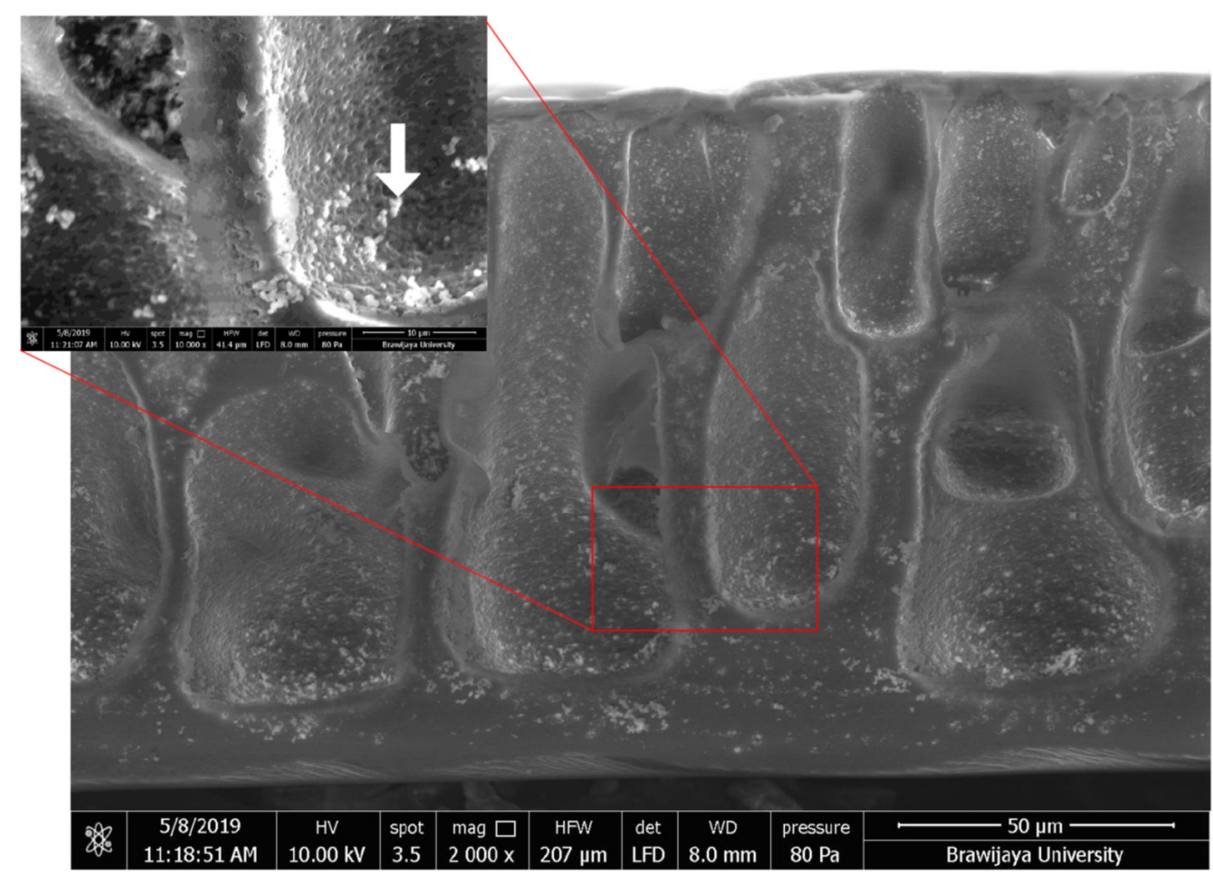

Figure 1. SEM image of mixed matrix membrane cross section. Active Olea europaea phenolic extract green nanoparticles as shown by white arrow (inset).

\subsection{Antibacterial Properties}

The performances of anti-biofouling mixed matrix membranes were investigated by measuring their permeability, mechanical strength, and bacterial adhesion onto the membrane surface. The E-coli adhesion onto membrane surface after immersing for $8 \mathrm{~h}$ are shown in Figure 2 and the percentage of bacterial adhesion are shown in Figure 3. The phenolic compound of Olea europaea nanoparticles were clearly observed to reduce bacterial attachment onto membrane surface as compared with pristine cellulose acetate membrane.

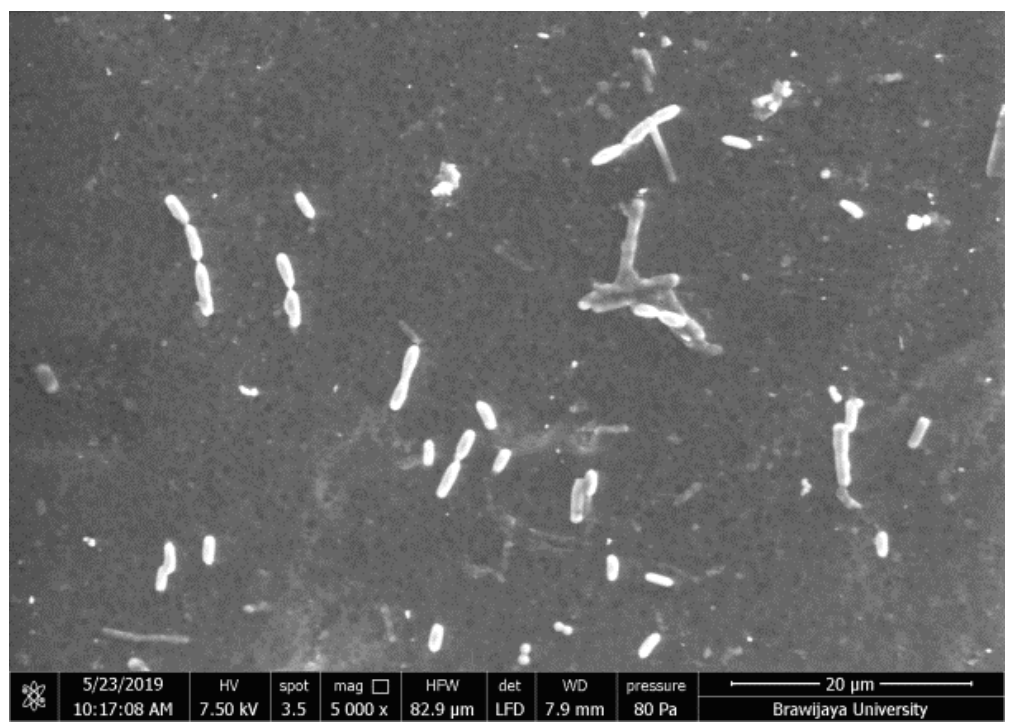

Figure 2. Eschericia coli adhesion on the membrane surface. 


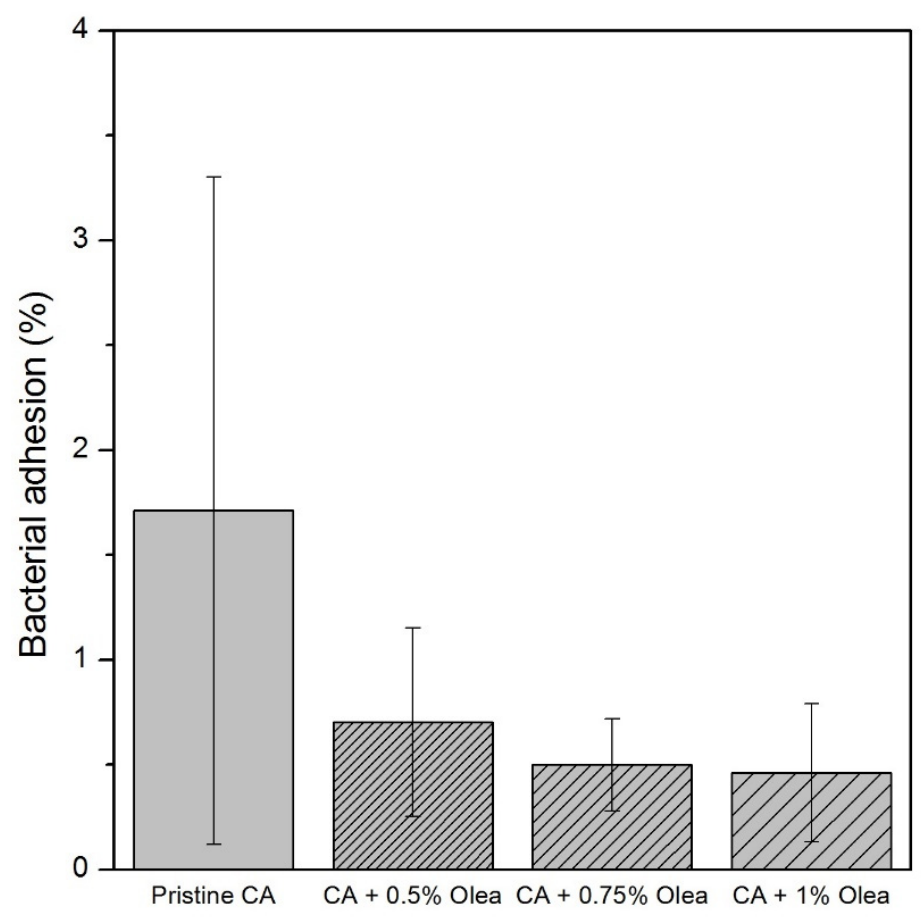

Figure 3. Bacterial adhesion using Eschericia coli onto surface of different membranes.

Phenols have antibacterial activity by interfering with the metabolism of microorganisms by damaging cell walls by penetrating them and denaturing the proteases of microorganism cells. Phenols contained in olive leaf extracts have been shown to reduce the percentage of bacterial adhesion on the membrane surface. However, the effect was dissimilar for another type of bacteria, i.e., Gram-positive bacteria such as Staphylococcus aureus. It is likely that the phenolic substances could not penetrate through the peptidoglycan of the bacteria. Moreover, the bacterial shape, i.e., spherical, has low surface-to-volume ratio, thus hindered the active contact to phenolic particles embedded in the membrane surface.

\section{Conclusions}

Natural and green antibiofoulant Olea europaea nanoparticles impregnated into cellulose acetate mixed matrix membrane could reduce biofouling growth. The promising results could produce a safe (food grade) membrane for food processing, in term of biofouling reduction, especially for microfiltration membrane application for juice clarification. Up-scaling into pilot scale is being considered to test the membrane performance in longterm experiments.

Author Contributions: Y.W. conceived and designed the experiments; S.A.R. and V.S.M. performed the experiments; Y.W., N.I. and A.W.P. analyzed the data; Y.W. wrote the paper, and N.I. and S.R.D. reviewed and revised the paper. All authors have read and agreed to the published version of the manuscript.

Funding: Ministry of Research, Technology and Higher Education, Republic of Indonesia

Institutional Review Board Statement: Not applicable.

Informed Consent Statement: Not applicable

Acknowledgments: The authors would like to thank Ministry of Research, Technology and Higher Education, Republic of Indonesia for research funding through University Superior Applied Research Grant (PTUPT) 2019-2021 scheme.

Conflicts of Interest: The authors declare no conflict of interest. 


\section{References}

1. Wibisono, Y. Two-Phase Flow for Fouling Control in Membranes; University of Twente: Enschede, The Netherlands, 2014.

2. De Barros, S.T.D.; Andrade, C.M.G.; Mendes, E.S.; Peres, L. Study of fouling mechanism in pineapple juice clarification by ultrafiltration. J. Membr. Sci. 2003, 215, 213-224.

3. Mondal, S.; Cassano, A.; Tasselli, F.; De, S. A generalized model for clarification of fruit juice during ultrafiltration under total recycle and batch mode. J. Membr. Sci. 2011, 366, 295-303.

4. $\quad$ Leam, J.J.; Bilad, M.R.; Wibisono, Y.; Wirzal, M.D.H.; Ahmed, I. Membrane technology for microalgae harvesting. In Microalgae Cultivation for Biofuels Production; Elsevier: Amsterdam, The Netherlands, 2020; pp. 97-110.

5. Wibisono, Y.; Ahmad, F.; Cornelissen, E.R.; Kemperman, A.J.B.; Nijmeijer, K. Dominant factors controlling the efficiency of twophase flow cleaning in spiral-wound membrane elements. Desalin. Water Treat. 2016, 57, 17625-17636.

6. Barambu, N.U.; Bilad, M.R.; Wibisono, Y.; Jaafar, J.; Mahlia, T.M.I.; Khan, A.L. Membrane surface patterning as a fouling mitigation strategy in liquid filtration: A Review. Polymers 2019, 11, 1687.

7. Creber, S.A.; Vrouwenvelder, J.S.; van Loosdrecht, M.C.M.; Johns, M.L. Chemical cleaning of biofouling in reverse osmosis membranes evaluated using magnetic resonance imaging. J. Membr. Sci. 2010, 362, 202-210.

8. Hausman, R.; Gullinkala, T.; Escobar, I.C. Development of copper-charged polypropylene feedspacers for biofouling control. J. Membr. Sci. 2010, 358, 114-121. 